\title{
In vivo and in silico evaluation of analgesic activity of Lippia alba
}

\author{
Md. Abdullah Aziz ${ }^{1}$, Manna Mehedi ${ }^{2}$, Mst. Irin Akter ${ }^{2}$, Sadiur Rahman Sajon ${ }^{1 *}$ (D) Kishor Mazumder ${ }^{1,3}$ and \\ Md. Sohel Rana ${ }^{4}$
}

\begin{abstract}
Background: This study was conducted to evaluate the analgesic activity of different extracts of Lippia alba (L. alba) along with in silico evaluation of analgesic activity of the isolated compounds from L. alba against cyclooxygenase- 2 enzyme and $\mathrm{ADME} / \mathrm{T}$ analysis of isolated compounds.
\end{abstract}

Method: In vivo analgesic activity of different extracts of $L$. alba was evaluated by acetic acid-induced writhing, tail immersion and hot plate on Swiss albino mice of either sex. In silico activity of the isolated compounds and ADME/T analysis were performed by Schrödinger-Maestro (Version 10.1) and OSIRIS Data warrior (version 4.6.1) softwares.

Results: Three different extracts (Methanolic extract: ME; Petroleum ether extract: PEE; Dichloromethane extract: DCME) of $250 \mathrm{mg} / \mathrm{kg}$ and $500 \mathrm{mg} / \mathrm{kg}$ doses were used in the experiments to evaluate analgesic activity. In acetic acid-induced writhing test, significant results were seen for PEE $(500 \mathrm{mg} / \mathrm{kg})$ and DCME $(500 \mathrm{mg} / \mathrm{kg})$, which were $53.09 \pm 2.87 \& 50.09 \pm$ $4.24 \%$, respectively. In tail immersion test, the best latency time was found at $+60 \mathrm{~min}$ for PEE $(500 \mathrm{mg} / \mathrm{kg})$ which is $(5.65 \pm 0.25) \mathrm{sec}$. For hot plate test, DCME at a dose $500 \mathrm{mg} / \mathrm{kg}$ showed the highest increase in latency time, which was $13.48 \pm 0.33 \mathrm{~s}$. In the case of in silico evaluation of analgesic activity, the compounds such as geranial, neral, (E)caryophyllene, caryophyllene oxide, mussaenide, and 8-epi-loganin meet the condition of Lipinski's rule of five. Among these safe compounds, 8-epi-loganin showed the best docking score of $-8.17 \mathrm{kcal} / \mathrm{mol}$ against cyclooxygenase-2 enzyme (PDB ID: 6COX), which was almost similar to that of the standard drug, Celecoxib $(-11.11 \mathrm{kcal} / \mathrm{mol})$.

Conclusion: In conclusion, L. alba can be a potent source of analgesic medicine and further modification and simulation studies are required to establish the effectiveness of 8-epi-loganin.

Keywords: Lippia alba, Analgesic, In-vivo, In silico

\section{Background}

Pain is an advantageous tool for the immune system to protect the area damaged by chemical, mechanical and thermal stimuli. But it brings a lot of discomfort and sufferings to the patients [1-4]. To manage the pain a wide varieties of analgesic like NSAIDs (Non-Steroidal Anti-Inflammatory Drugs), steroidal drugs as well as opioid analgesics are used which have various adverse effect such as liver damage, cardiovascular problems, renal failure, erectile dysfunction, manic depression, hypertension, cramps and dizziness, appearance of dormant diabetes, skin atrophy, decreased bone density, gastrointestinal tract

\footnotetext{
* Correspondence: sadiur.sajon@yahoo.com

${ }^{1}$ Department of Pharmacy, Jashore University of Science and Technology, Jashore-7408, Jashore, Bangladesh

Full list of author information is available at the end of the article
}

ulcers, dependence, constipation and respiratory problems [5-9]. So, it's an important concern to the world to make sure a source of affordable alternative herbal based analgesic drugs with more potent as well as less adverse effect that may be acquired through medicinal plant.

Molecular docking is an important technique of making plans and layout of new drugs, where it is expected that a small molecule will show affinity and bind experimentally to the binding site of the target receptor. A successful docking methodology should correctly predict the native ligand model to the receptor binding site (i.e. to find the experimental ligand geometry within a certain tolerance limit) and the associated physico-chemical molecular interactions $[10,11]$.

L. alba (Family: Verbenaceae) is a $1.7 \mathrm{~cm}$ high aromatic shrub that is widely distributed through the 
Caribbean, South and Central America and Tropical Africa $[12,13]$. It is widely cultivated for its ornamental value as it has aromatic foliage and beautiful flowers [14]. The leaves are used for flavoring agents [15] such as mole sauces from Oaxaca, Mexico [16]. The plant is used traditionally for colds, sedative, somatic, cough, antidepressant, dysentery, analgesic, febrifuge and gastrointestinal ailments [17, 18]. A review of the literature showed that $L$. alba has been found to have a wide range of activities, including antioxidant, antiulcer, antibacterial, antifungal, antinociceptive, antiviral, anti-inflammatory, antiprotozoal, cytotoxic, as well as neurosedative activities [18-21]. Many volatile and non-volatile components such as neral, geranial, E-caryophyllene, caryophyllene oxide, allo-aromadendrene, theveside, 8epiloganin, geniposide, mussaenoside, apigenin-7-O-glucuronide, luteoline-7-O-glucuronide etc. [22, 23] have been isolated from this plant.

Therefore, the aim of this study was to investigate the analgesic activity of the methanolic (ME), petroleum ether (PEE) and dichloromethane (DCME) extracts of $L$. alba leaves via in vivo method and in silico identification of potential phyto compound as an analgesic.

\section{Materials and methods}

\section{Plant collection and identification}

The fresh leaves of $L$. alba were collected from section16 (near the rose garden) of National Botanical Garden of Bangladesh, Mirpur-2, Dhaka. The collected plant was identified by Sarder Nasir Uddin, Principal Scientific Officer, Bangladesh National Herbarium (Accession Code- 38307). A dried sample was placed in the herbarium for confirming later reference.

\section{Preparation of plant extract}

The collected leaves were washed with fresh water and dried under shade at room temperature for a period of 7 days. Then, the dried sample was ground to fine powder by using mechanical grinder (MACSALAB 200 Cross Beater, Eriez, Erie, Pennsylvania, U.S.A.) and 40mesh sieve. After that the powdered leaves $(83.4 \mathrm{~g})$ were extracted by using different solvents such as methanol, petroleum ether and dichloromethane separately, whereas hot extraction method was followed with the help of a soxlet apparatus. In fact, $300 \mathrm{~mL}$ respective solvent was used for completing the extraction process. Moreover, the filtration was carried out for getting the liquid extracts by using Whatman No.1 filter papers. Next, a hot air oven (BST/HAO-1127, Bionics Scientific Technologies Pvt. Ltd., Delhi, India) was used for drying the individual filtrate at $40{ }^{\circ} \mathrm{C}$. Here, the extraction yield of ME, PEE and DCME were $4.72 \%(w / w), 3.88 \%(w / w)$ and $3.53 \%(\mathrm{w} / \mathrm{w})$ respectively. These extracts were then stored at $4{ }^{\circ} \mathrm{C}$ with a view to conducting analgesic study.

\section{Experimental animals}

For the analgesic study, 120 Swiss Albino mice of either sex, 6-7 weeks of age, weighing between 20 and $30 \mathrm{~g}$, were collected from the Animal Research Branch of the International Center for Diarrheal Disease and Research, Bangladesh (ICDDR, B). They were housed in groups of 5 , in plastic cages having dimension of $(28 \times 22 \times 13 \mathrm{~cm})$. Soft wood shavings were used as bedding of cages. Animals were maintained under standard environmental conditions i.e. temperature: $\left(27.0 \pm 1.0{ }^{\circ} \mathrm{C}\right)$, relative humidity: $55-65 \%$ and $12 \mathrm{~h}$ light $/ 12 \mathrm{~h}$ dark cycle. Pellets of food and water ad libitum were confirmed for mice. The newly bought mice were given a week rest to get habituated in the room environment. The Institutional Animal Ethical Committee of Jashore University of Science and Technology, Jashore, Bangladesh approved the protocol used in these experiments conducted with these animals.

\section{Acute oral toxicity study}

Some adverse effects may result within $24 \mathrm{~h}$ from single or multiple exposures of materials which indicate acute toxicity. $\mathrm{LD}_{50}$ of the test sample is found from this study following OECD guidelines. Different concentrations of test samples like 100, 250, 500, 1000, 2000, 3000 and $4000 \mathrm{mg} / \mathrm{kg}$ body weight were employed orally. Either sign of any toxicity or mortality that was found after oral administration of the samples was monitored up to $1 \mathrm{~h}$. For the next $5-6 \mathrm{~h}$, animals were observed on every hour basis. Nevertheless, the animals were reserved under observation for 2 weeks [24].

\section{Evaluation of analgesic activity Acetic acid induced writhing test}

The writhing test was conducted according to the method of Koster et al [25]. Fourty mice were divided into control group (normal water), positive control or standard group (diclofenac sodium, DS, $100 \mathrm{mg} / \mathrm{kg}$ body weight), and test groups (ME, PEE and DCME at 250 and $500 \mathrm{mg} / \mathrm{kg}$ body weight), containing five mice in each group. Mice in the control group, positive control group and test groups received one dose of normal water, diclofenac sodium, methanolic, petroleum ether and dichloromethane extracts of $L$. alba leaves orally. Forty-five minutes later, each mouse was injected intraperitoneally with $0.7 \%(\mathrm{v} / \mathrm{v})$ acetic acid at a dose of 10 $\mathrm{mL} / \mathrm{kg}$ body weight. Fifteen minutes after the administration of acetic acid, the number of writhing responses was recorded for each animal during a 5 -min period. Besides, the mean abdominal writhing for each group was calculated.

\section{Tail immersion test}

The method of Toma et al [26] was used to assess the central analgesic activity. Also for this study, fourty mice 
were divided into control group (normal water), positive control or standard group (diclofenac sodium, DS, 100 $\mathrm{mg} / \mathrm{kg}$ body weight), and test groups (ME, PEE and DCME at 250 and $500 \mathrm{mg} / \mathrm{kg}$ body weight), containing five mice in each group. Here the painful reactions in animals were generated by thermal stimulus through dipping the tip of the tail in hot water. Mice were grouped and treated as described before. Morphin (5 $\mathrm{mg} / \mathrm{kg}$ ) was used as the reference drug. After the treatment of each group, the basal reaction time was measured by immersing the tail tips of the mice (last 1-2 $\mathrm{cm})$ in hot water of $(55 \pm 1){ }^{\circ} \mathrm{C}$. The flick response of mice, i.e., time taken (in second) to withdraw it from hot water source was calculated and results were compared with the control group. A latency period of $15 \mathrm{~s}$ was set as the cut-off point to avoid injury to mice. The latent period of the tail-flick response was determined before $30 \mathrm{~min}$ and after 30, 60 and $90 \mathrm{~min}$ of drug and extract administration.

\section{Hot plate method}

Fourty mice were divided into control group (normal water), positive control or standard group (diclofenac sodium, DS, $100 \mathrm{mg} / \mathrm{kg}$ body weight), and test groups (ME, PEE and DCME at 250 and $500 \mathrm{mg} / \mathrm{kg}$ body weight), containing five mice in each group as well for the study of hot plate method. The paws of mice are very sensitive to temperature at $55 \pm 0.5^{\circ} \mathrm{C}$, which are not damaging to the skin. The animals were placed on hot plate kept at a temperature of $55 \pm 0.5^{\circ} \mathrm{C}$. A cut off period of 20s [26] was observed to avoid damage to the paw. Reaction time was recorded when animals licked their fore or hind paws or jumped at 0 (before $30 \mathrm{~min}$ of drug administration), $+30,+60$ and +90 min after oral administration of the samples. The animals of test groups received test samples of different extracts at the doses of 250 and 500 $\mathrm{mg} / \mathrm{kg}$ body weight. Positive control group or standard group and control group were treated with morphine (5 $\mathrm{mg} / \mathrm{kg}$ b.w.) and water $(10 \mathrm{ml} / \mathrm{kg})$, respectively.

\section{In silico molecular docking analysis}

For molecular docking study, Glide of SchrödingerMaestro (Version 10.1) was used to predict the potent active compounds isolated from $L$. alba compared to standard drug celecoxib against the active inhibitory site of Cyclooxygenase enzyme.

\section{Ligand and protein preparation}

The 3D structure of the enzyme Cyclooxygenase- 2 was obtained from protein data bank in PDB format (PDB ID: 6COX) [27]. In the beginning, the protein structure was purified in discovery studio $\mathrm{v} 4.45$ by removing the $B$ chain and bound ligands to B chain and protoporphyrin IX containing Fe \& N-acetyl-D-glucosamine bound to A chain. The purified structure was saved in PDB format (Discovery Studio is a suite of software for simulating small molecule and macromolecule systems. It is developed and distributed by Accelrys). Protein Preparation Wizard of Schrödinger-Maestro v 10.1 was used to make the protein compatible for Glide module. In this process, in primary stage, bond order was assigned, hydrogen molecules were added, zero-order bonds with metal were created, disulfide bonds were created and selenomethionines were converted to methionines. In protein refinement stage, hydrogen bonds were assigned using the PROPKA module at $\mathrm{pH} 7$, water molecules with less than three hydrogen bonds to non-water molecules were removed and at last energy minimization was carried out using OPLS 2005 force field setting the maximum heavy atom RMSD to $30 \AA$ [28].

\section{Grid generation}

Glide version 6.6 was used for receptor grid generation. Glide is a module which is used for excluding the ligand from ligand-protein complex and defining a box where the desired ligands can be added as a compex. In this study, van der waals radius scaling was set to default of scaling factor $1.00 \AA$ and charge cut-off $0.25 \AA$. A cubic box of specific dimensions centered on the centroid of the active site residues was generated for the receptor. The bounding box was set to $14 \AA \times 14 \AA \times 10 \AA$ and it's essential to identify the active binding site in the target protein [29].

\section{Glide standard precision (SP) ligand docking}

After completing the preliminary steps, the glide 6.6 module of Schrödinger-Maestro v 10.1 was used for determining the docking scores of desired complex. Glide is designed to assist in high-throughput screening of potential ligands based on binding mode and affinity for a given receptor molecule. We can compare ligand scores with those of other test ligands, or compare ligand geometries with those of a reference ligand. Additionally, we can use Glide to generate one or more plausible binding modes for a newly designed ligand. In this study, Flexible ligand docking was performed with Glide of Schrödinger-Maestro (version 10.1) [30, 31] within which penalties were applied to non-cis/trans amide bonds. Glide standard precision docking was performed with these molecules, and hits above $4 \mathrm{kcal} / \mathrm{mol}$ based on docking score with COX-2 enzyme in XP mode, keeping all docking parameters as default. No bonding constraints were given during docking calculations. Using Monte Carlo random search algorithm, ligand poses were generated for each input molecule, and binding affinity of these molecules to the COX-2 enzyme were predicted regarding Glide docking score. Post- 
docking minimization was performed with OPLS 2005 force field, and one pose per ligand was saved.

\section{ADME and toxicity analysis}

The appropriate physicochemical properties of a molecule to pass a orally active drug molecule depends upon certain physical and chemical parameters also known Lipinski's rule of five or simply the Rule of Five (RO5). The rule describes the physicochemical properties important for a drugs pharmacokinetic in the human body such as absorption, distribution, metabolism and excretion (ADME) but the rule cannot confirm the pharmacodynamics property of the drug molecule [32]. In our study, to evaluate the ADME and toxicity properties of the isolated compounds from $L$. alba, we used OSIRIS Data warrior v 4.6.1 software. In this software, we used the chemical structure feature to calculate the desired properties for ADME/T analysis.

\section{Statistical analysis}

All results are expressed as mean \pm standard error of mean (SEM). All the tests were analyzed statistically by one-way ANOVA (Analysis of Variance) followed by Dunnett's t test and Post Hoc Tuckey's test. In addition, the results of tail immersion test and Hot Plate test were analyzed by using repeated measure ANOVA (RMANOVA). $P<0.05$ was considered to be statistically significant. $\mathrm{P}<0.05$ was considered to be statistically significant. All data were analyzed using SPSS software (version 17; IBM Corporation, New York, USA).

\section{Results}

\section{In vivo analgesic activity}

In the acetic acid induced writhing test, all mice displayed significant number of writhing compared to control. Treatment with diclofenac sodium showed the lowest number of writhing compared to any other
Table 1 Effects of different extracts of $L$. alba in acetic acidinduced writhing test

\begin{tabular}{lllll}
\hline Treatment group & Dose & $\mathrm{n}$ & Number of writhing & Inhibition (\%) \\
\hline Control & $10 \mathrm{ml} / \mathrm{kg}$ & 5 & $56.5 \pm 5.80$ & - \\
$\begin{array}{l}\text { Standard } \\
\text { (Diclofenac Sodium) }\end{array}$ & $100 \mathrm{mg} / \mathrm{kg}$ & 5 & $10.75 \pm 3.83^{*}$ & $78.61 \pm 9.60^{*}$ \\
ME & $250 \mathrm{mg} / \mathrm{kg}$ & 5 & $37.50 \pm 1.70^{* a}$ & $31.94 \pm 5.80^{*}$ \\
ME & $500 \mathrm{mg} / \mathrm{kg}$ & 5 & $27.00 \pm 1.87^{* a}$ & $49.30 \pm 9.48^{*}$ \\
PEE & $250 \mathrm{mg} / \mathrm{kg}$ & 5 & $36.25 \pm 0.85^{* a}$ & $33.89 \pm 6.40^{*}$ \\
PEE & $500 \mathrm{mg} / \mathrm{kg}$ & 5 & $26.00 \pm 1.35^{* a}$ & $53.09 \pm 2.87^{*}$ \\
DCME & $250 \mathrm{mg} / \mathrm{kg}$ & 5 & $37.5 \pm 2.10^{* a}$ & $30.89 \pm 9.80^{*}$ \\
DCME & $500 \mathrm{mg} / \mathrm{kg}$ & 5 & $27.50 \pm 1.19^{* a}$ & $50.09 \pm 4.24^{*}$ \\
\hline
\end{tabular}

Number of writhing is present as mean \pm standard error of mean. ${ }^{*} P<0.05$, vs control (Dunnett's $\mathrm{t}$ test); ${ }^{\mathrm{a}} P<0.05$, vs Standard group (pair-wise comparison by post-hoc Tukey's HSD test). ME: methanolic extract; PEE: petroleum ether extract; DCME: dichloromethane extract

treatment groups with extract. Among the treatment groups with extract PEE $(500 \mathrm{mg} / \mathrm{kg})$ and DCME $(500$ $\mathrm{mg} / \mathrm{kg}$ ) showed significant inhibition (\%) which is $(53.09 \pm 2.87) \% \&(50.09 \pm 4.24) \%$ respectively. The results are presented in Table 1.

In Table 2, the results of tail immersion test of analgesic activity evaluation are represented. Here we can see that at $+60 \mathrm{~min}$ all the extracts except DCME $(250$ $\mathrm{mg} / \mathrm{kg}$ ) displayed significant increase in latency time.

Table 3 represents the results of hot plate taste. At time +90 min all the extracts along with standard drug displayed significant increase in latency time compared to control group. Among the extracts DCME $(500 \mathrm{mg} /$ $\mathrm{kg}$ ) showed the best increased latency time which is $(13.48 \pm 0.33)$ sec.

In silico study for the evaluation of analgesic activity Table 4 represents the physicochemical properties required for ADME/T analysis of the isolated compounds

Table 2 Effects of different extracts of L. alba in tail immersion test

\begin{tabular}{|c|c|c|c|c|c|c|}
\hline \multirow{2}{*}{$\begin{array}{l}\text { Treatment } \\
\text { group }\end{array}$} & \multirow[t]{2}{*}{ Dose } & \multirow[t]{2}{*}{$\mathrm{n}$} & \multicolumn{4}{|c|}{ Latency Time (s) } \\
\hline & & & $0 \mathrm{~min}$ & $+30 \mathrm{~min}$ & $+60 \mathrm{~min}$ & $+90 \mathrm{~min}$ \\
\hline Control & $10 \mathrm{ml} / \mathrm{kg}$ & 5 & $2.39 \pm 0.21$ & $3.85 \pm 0.05$ & $3.53 \pm 0.10$ & $3.02 \pm 0.14$ \\
\hline Morphin & $5 \mathrm{mg} / \mathrm{kg}$ & 5 & $4.59 \pm 0.29^{*}$ & $11.31 \pm 0.19^{*}$ & $11.55 \pm 0.21^{*}$ & $11.26 \pm 0.37^{*}$ \\
\hline ME & $250 \mathrm{mg} / \mathrm{kg}$ & 5 & $3.68 \pm 0.29^{*}$ & $2.92 \pm 0.42$ & $2.94 \pm 0.20^{*}$ & $3.43 \pm 0.15$ \\
\hline ME & 500 mg/kg & 5 & $4.25 \pm 0.07^{*}$ & $4.53 \pm 0.12$ & $4.68 \pm 0.15^{*}$ & $3.15 \pm 0.15$ \\
\hline PEE & $250 \mathrm{mg} / \mathrm{kg}$ & 5 & $3.11 \pm 0.12$ & $3.14 \pm 0.33$ & $4.46 \pm 0.18^{*}$ & $3.02 \pm 0.14$ \\
\hline PEE & 500 mg/kg & 5 & $4.08 \pm 0.32$ & $3.87 \pm 0.42$ & $5.65 \pm 0.25^{*}$ & $5.25 \pm 0.79^{*}$ \\
\hline DCME & 250 mg/kg & 5 & $3.63 \pm 0.33^{*}$ & $3.57 \pm 0.36$ & $3.35 \pm 0.13$ & $3.39 \pm 0.18$ \\
\hline DCME & 500 mg/kg & 5 & $4.29 \pm 0.23^{*}$ & $3.96 \pm 0.25$ & $4.80 \pm 0.32^{*}$ & $3.39 \pm 0.79$ \\
\hline
\end{tabular}

Latency time values are present as mean \pm standard error of mean. 0 min means 30 min before drug administration, +30 min, +60 min and +90 min indicate 30 , 60 and $90 \mathrm{~min}$ after the administration of drug and extract, respectively. Tests of within-subjects effects reveal that for the factor 'Time' calculated $\mathrm{F}=13.55$ for all methods and $P$ value $=0.000$ in every case. So time is highly significant at any level of significance. ${ }^{*} P<0.05$, vs control. Repeated measure analysis of variance with Dunnett's multiple comparison was performed to analyze this data set. ME: methanolic extract; PEE: petroleum ether extract; DCME: dichloromethane extract 
Table 3 Effects of different extracts of L. alba in hot plate test

\begin{tabular}{lllllll}
\hline $\begin{array}{l}\text { Treatment } \\
\text { group }\end{array}$ & Dose & $\mathrm{n}$ & & Latency Time $(\mathrm{s})$ & & \\
\cline { 5 - 6 } & & & $0 \mathrm{~min}$ & $+30 \mathrm{~min}$ & $+60 \mathrm{~min}$ & $+90 \mathrm{~min}$ \\
\hline Control & $10 \mathrm{ml} / \mathrm{kg}$ & 5 & $6.67 \pm 0.08$ & $6.90 \pm 0.38$ & $9.77 \pm 0.40$ & $9.18 \pm 0.16$ \\
Morphine & $5 \mathrm{mg} / \mathrm{kg}$ & 5 & $8.52 \pm 0.08^{*}$ & $10.50 \pm 0.42^{*}$ & $11.99 \pm 0.31^{*}$ & $13.96 \pm 0.10^{*}$ \\
ME & $250 \mathrm{mg} / \mathrm{kg}$ & 5 & $6.35 \pm 0.14$ & $8.36 \pm 0.31$ & $10.58 \pm 0.98$ & $12.09 \pm 0.26^{*}$ \\
ME & $500 \mathrm{mg} / \mathrm{kg}$ & 5 & $6.91 \pm 0.10$ & $9.36 \pm 0.38^{*}$ & $10.49 \pm 0.56$ & $13.13 \pm 0.53^{*}$ \\
PEE & $250 \mathrm{mg} / \mathrm{kg}$ & 5 & $6.90 \pm 0.10$ & $8.29 \pm 0.49$ & $10.42 \pm 0.38$ & $10.94 \pm 0.58^{*}$ \\
PEE & $500 \mathrm{mg} / \mathrm{kg}$ & 5 & $7.20 \pm 0.14$ & $9.31 \pm 0.19^{*}$ & $11.86 \pm 0.26^{*}$ & $13.25 \pm 0.45^{*}$ \\
DCME & $250 \mathrm{mg} / \mathrm{kg}$ & 5 & $5.53 \pm 0.34$ & $7.71 \pm 0.42$ & $10.77 \pm 0.29$ & $13.16 \pm 0.51^{*}$ \\
DCME & $500 \mathrm{mg} / \mathrm{kg}$ & 5 & $5.84 \pm 0.50$ & $9.41 \pm 0.20^{*}$ & $12.00 \pm 0.17^{*}$ & $13.48 \pm 0.33^{*}$ \\
\hline
\end{tabular}

Latency time values are present as mean \pm standard error of mean. 0 min means 30 min before drug administration, $+30 \mathrm{~min},+60 \mathrm{~min}$ and +90 min indicate 30 60 and $90 \mathrm{~min}$ after drug and extract administration, respectively. Tests of within-subjects effects reveal that for the factor 'Time' calculated $\mathrm{F}=38.472$ for all methods and $P$ value $=0.000$ in every case. So time is highly significant at any level of significance. ${ }^{*} P<0.05$, vs control. Repeated measure analysis of variance with Dunnett's multiple comparison was performed to analyze this data set. ME: methanolic extract; PEE: petroleum ether extract; DCME: dichloromethane extract

of $L$. alba. From this table, by analyzing the obtained value we can predict the eligibility of a compound to pass as a safe compound. We can see that Theveside, Apigenin 7-O-glucuronide and Luteolin 7-Oglucuronide made violations to Lipinski's rule of five but all other molecules met the conditions to pass as a drug molecule according to the rule.

In Table 5, the identification number for the safe isolated compounds are presented as InChI key format and also the docking score, glide e model and glide energy of the isolated compounds along with standard drug Celecoxib is represented. From the table we can see that 8epiloganin has the lowest docking score $-8.17 \mathrm{kcal} / \mathrm{mol}$. Interactions of this compound and standard drug Celecoxib with cyclooxygenase- 2 protein, their binding interaction with the specific amino acids of the inhibitory site of the protein is displayed in Figs. 1, 2, 3.

\section{Discussion}

Phytoconstituents are obtained by extraction of plant parts and may be responsible for wide range of therapeutic activity when they are used in medicinal purpose [33]. Secondary metabolites are mainly responsible for pharmacological action. Though primary metabolites are found in almost all plants, not all secondary metabolites are found in every plant but they differ from one plant to another. For this very reason, not all plants shows every kind of pharmacologic or therapeutic action [34] and as a consequence in the field of drug discovery, identifying the phytoconstituents is a major step [35].

In the acetic acid induced writhing test, injection of $0.7 \%$ acetic acid i.p. induces localized inflammation by the discharge of arachidonic acid from tissue phospholid, which is a pain stimuli [36]. It is proved that peripheral pain is induced by either peritoneal mast cells [37] or

Table 4 ADME and toxicity analysis of the phytoconstituents isolated from L. alba OSIRIS Data warrior

\begin{tabular}{|c|c|c|c|c|c|c|}
\hline Chemical name & $\mathrm{MW}(\mathrm{g} / \mathrm{mol})$ & $\mathrm{HBA}$ & $\mathrm{HBD}$ & $C \log P$ & Molar Refractivity & No of violations \\
\hline Geranial & 152.23 & 1 & 0 & 3.27 & 49.44 & 0 \\
\hline Neral & 152.23 & 1 & 0 & 3.27 & 49.44 & 0 \\
\hline (E)-Caryophyllene & 204.35 & 0 & 0 & 5.49 & 68.78 & 0 \\
\hline Caryophyllene Oxide & 220.35 & 1 & 0 & 4.06 & 68.27 & 0 \\
\hline Allo-aromadendrene epoxide & 220.35 & 1 & 0 & 2.92 & 66.63 & 0 \\
\hline Theveside & 390.34 & 11 & 7 & -3.40 & 83.77 & 1 \\
\hline 8-epi-loganin & 390.38 & 10 & 5 & -1.97 & 87.37 & 0 \\
\hline Mussaenoside & 390.38 & 10 & 5 & -1.94 & 87.40 & 0 \\
\hline Apigenin 7-O-glucuronide & 446.36 & 11 & 6 & -0.0032 & 106.72 & 2 \\
\hline Luteolin 7-O-glucuronide & 462.36 & 12 & 7 & -0.35 & 108.74 & 2 \\
\hline
\end{tabular}

Molecular weight (MW) acceptable range $<500$

Hydrogen bond acceptor (HBA) range $\leq 10$

Hydrogen bond donor (HBD) range $\leq 5$

High lipophilicity (expressed as $c$ logP, acceptable range $<5$ )

Molar refractivity should be between 40 to 130 
Table 5 Docking result of Celecoxib and phytoconstituents isolated from L. alba with Cyclo-oxygenase-2 (PDB: 6COX) for analgesic activity

\begin{tabular}{|c|c|c|c|c|}
\hline Isolated compounds & InChl Key & Docking Score (kcal/mol) & Glide e model (kcal/mol) & Glide energy (kcal/mol) \\
\hline Celecoxib & RZEKVGVHFLEQIL-UHFFFAOYSA-N & -11.11 & -88.78 & -56.89 \\
\hline Geranial & WTEVQBCEXWBHNA-JXMROGBWSA-N & -4.64 & -30.92 & -24.31 \\
\hline Neral & WTEVQBCEXWBHNA-YFHOEESVSA-N & -4.27 & -29.83 & -23.98 \\
\hline (E)-Caryophyllene & NPNUFJAVOOONJE-GFUGXAQUSA-N & -7.61 & -25.64 & -18.35 \\
\hline Caryophyllene Oxide & NVEQFIOZRFFVFW-RGCMKSIDSA-N & -6.77 & -33.25 & -3.11 \\
\hline Allo-aromadendrene epoxide & XPGWKKLDFXNBPJ-PVNZKTJZZSA-N & -7.97 & -38.98 & -21.11 \\
\hline 8-epi-loganin & AMBQHHVBBHTQBF-OZIIXKNCSA-N & -8.17 & -38.66 & -32.41 \\
\hline Mussaenoside & XBGJTRDIWPEIMG-DUMNYRKASA-N & -7.28 & -34.58 & -22.13 \\
\hline
\end{tabular}

acid sensing ion channels [38] or PG pathway [39]. Table 1 represents the peripheral analgesic effect of different extracts of $L$. alba.

Tail immersion and hot plate taste are another method for determining peripheral analgesic activity [26]. Centrally acting analgesics and opoid receptor agonists are more effectively evaluated by these two methods. Opoid receptor agonists act through spinal and supra spinal receptors and among these receptors $\mu$ receptor agonist is most effective against thermal induced nociception [40, 41]. And for this, tail immersion and hot plate are very effective to evaluate the peripheral analgesic activity. Tables 2 and 3 represents the analgesic activity of $L$. alba in tail immersion test and hot plate taste.
To identify potential compounds isolated from $L$. alba for analgesic activity, at first, we analyzed the compatibility of the compounds to be used as drug molecule. For this purpose, we analyzed some parameters such as molecular weight $(<500 \mathrm{~g} / \mathrm{mol})$, hydrogen bond acceptor $(\leq 10)$, hydrogen bond donor $(\leq 5)$, clogP $(<5)$, molar refractivity $(40-130)$ of the isolated compounds and in Table 4 we can see that seven compounds out of the ten considered compounds, have the potentiality to be used as a drug candidate.

Next, we demonstrated molecular docking score as well as glide e model score and glide energy score of the isolate compounds of $L$. alba with cyclooxygenase-2 enzyme to evaluate the analgesic activity of the plant in

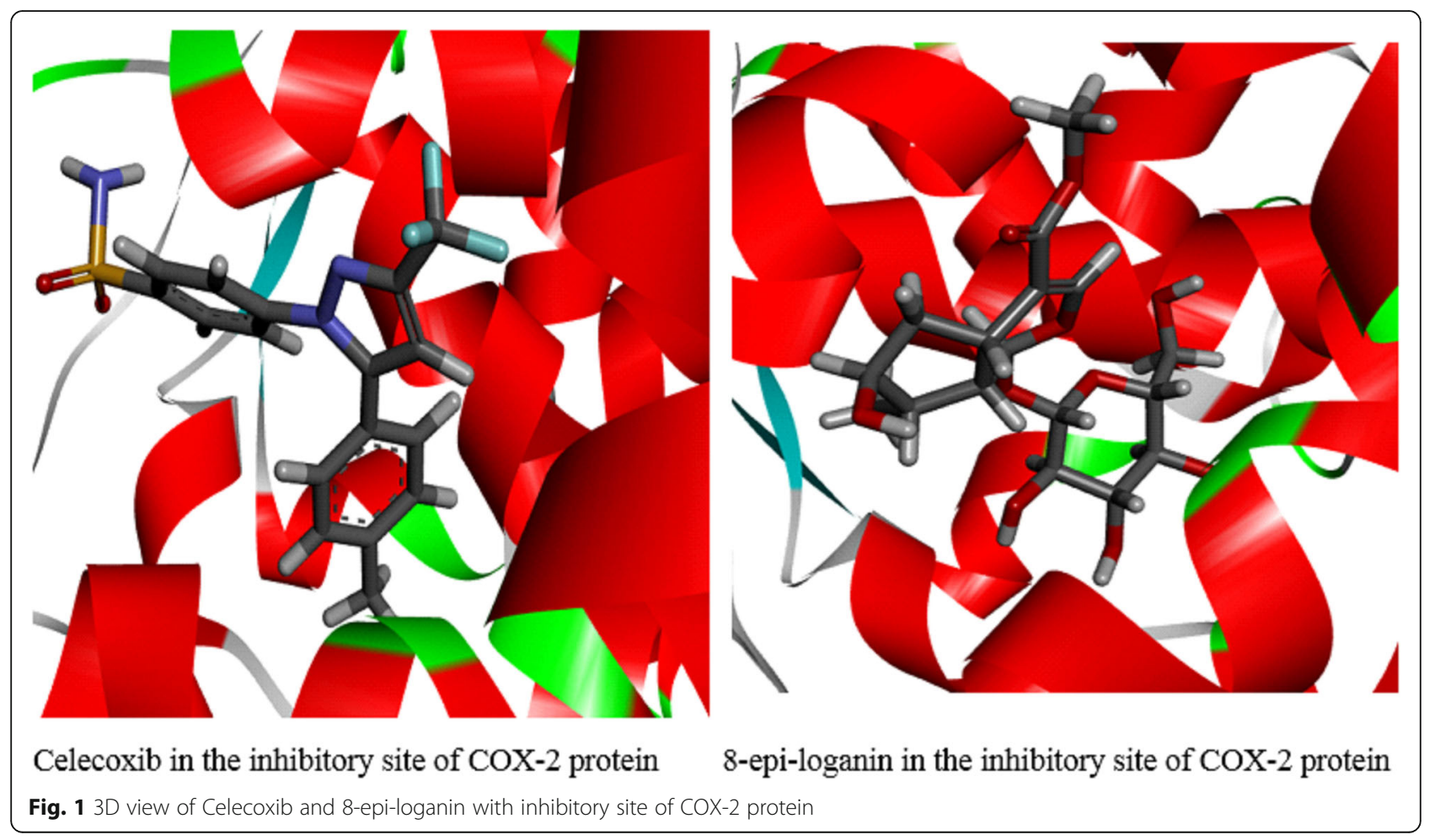




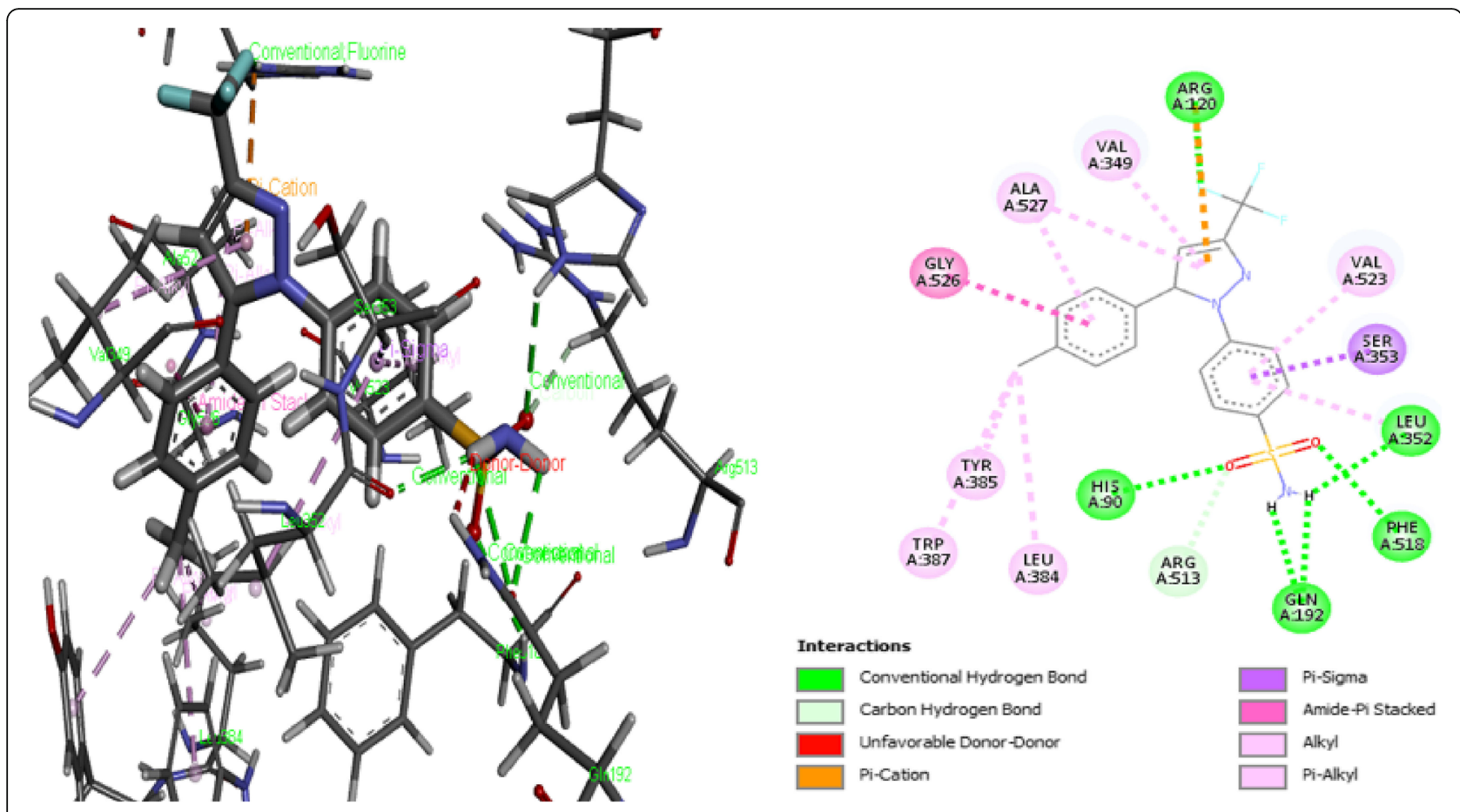

Fig. 2 2D and 3D binding types of Celecoxib binding with specific amino acids of cyclooxygenase-2 enzyme
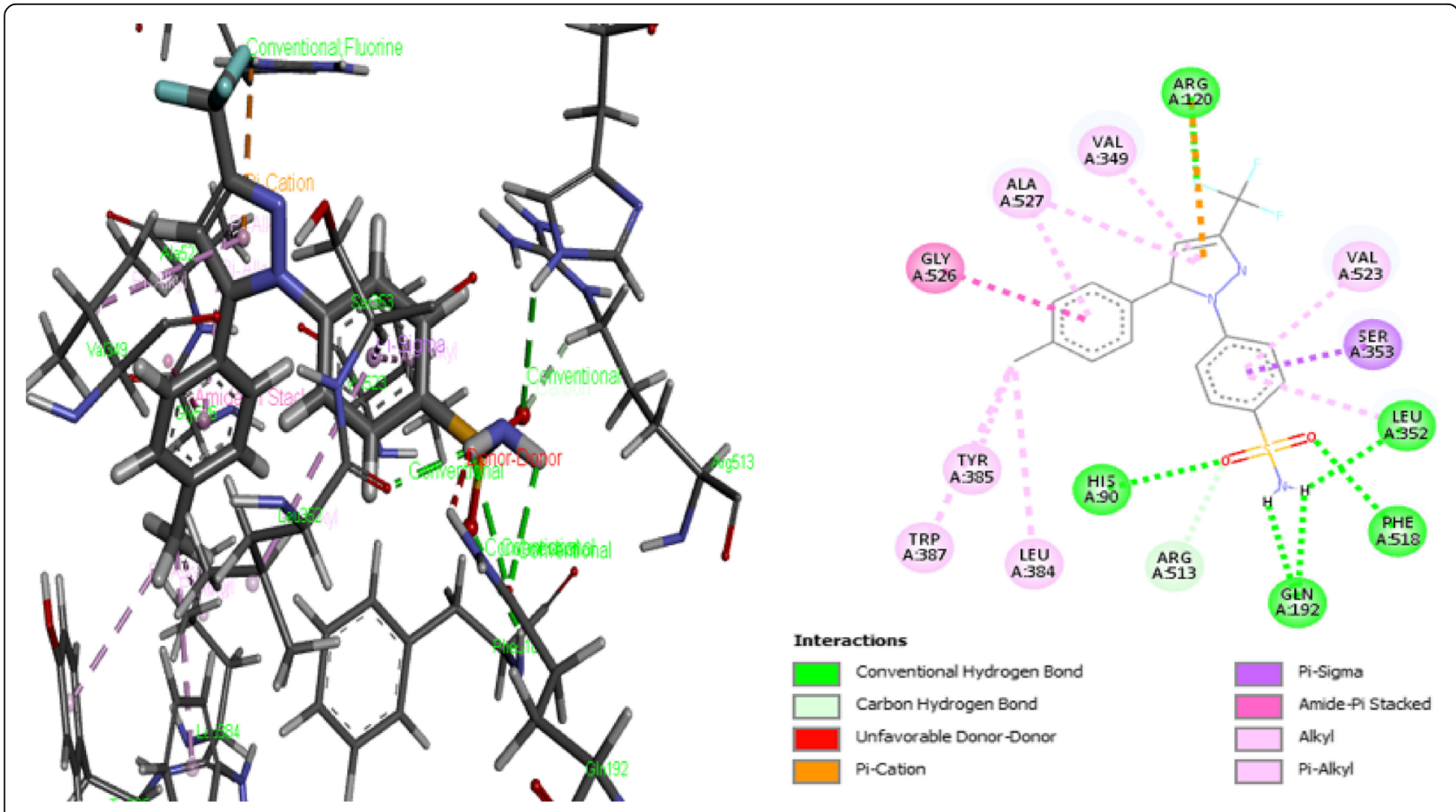

Fig. $32 \mathrm{D}$ and 3D binding types of 8-epi-loganin binding with specific amino acids of cyclooxygenase-2 enzyme 
molecular level which is demonstrated in Table 5. Cyclooxygenase- 2 enzyme is mainly responsible for acute pain and selective cox- 2 inhibitors are a better choice to stop the pain stimulating action [42] but cox-2 inhibitors are associated with a wide range of side effects [43] and for this finding replacement of selective cox-2 inhibitors or coxib drugs to selectively antagonize cox-2 enzyme is necessary. In our study, 8-epi-loganin showed good docking score $(-8.17 \mathrm{kcal} / \mathrm{mol})$ against cox- 2 enzyme whereas our standard drug Celecoxib showed docking score of $-11.11 \mathrm{kcal} / \mathrm{mol}$, which is comparable to our compounds. So, it may be possible that this compound may act as a promising hit for selective cox-2 inhibition.

\section{Conclusion}

Medicinal plants are the best source of medication for human kinds with a wide range of activity. It is up to us to find out the necessary plants and isolate the responsible phytochemicals for the desired activity and optimize them to make them better with less side effects and better potency. In this purpose, different extracts of L. alba were evaluated for analgesic activity and we found that it has significant analgesic property in vivo. Moreover, in silico docking and ADME/T analysis was performed to find out the possible responsible molecule for conducting analgesia. In our study, we found that 8epi-loganin had the possibility to act as a selective cox-2 (responsible for acute pain) inhibitor. B, as this is a crude study, so, further rigorous study is required to establish this compound as a potent analgesic druggable molecule.

\section{Abbreviations}

ADME/T: absorption distribution metabolism excretion toxicity; COX2: cyclooxygenase-2; DCME: dichloromethane extract; ME: methanolic extract; PEE: petroleum ether extract; PG: prostaglandin; RMSD: Root-mean-square deviation

\section{Acknowledgements}

The authors are grateful to the Department of Pharmacy, Jashore University of Science and Technology, Jashore, Bangladesh and Department of Pharmacy, Stamford University Bangladesh for providing facilities to carry out the research work

\section{Authors' contributions \\ Concept - MAA; Design - MAA; MMM; KM; Supervision - KM; MSR; Resources - MAA; MMM; MIA; Materials - MAA; MMM; SRS; Data Collection and/or Processing - MAA; MMM; MIA; Analysis and/or Interpretation - MAA MMM; MIA; SRS; Literature Search - MAA; MMM; MIA; SRS; Writing - MAA; MMM; MIA; SRS; Critical Reviews - MAA; MMM; MIA; SRS; KM; MSR; All authors read and approved the final manuscript.}

\section{Funding}

The study was done through self-finance.

\section{Availability of data and materials}

The datasets supporting the conclusions of this article are included within the article.

\section{Ethics approval}

The study protocol was approved by the institutional animal ethical committee of Jashore University of Science and Technology, Jashore, Bangladesh.

\section{Consent for publication}

Not applicable.

\section{Competing interests}

The authors declare that they have no competing interests.

\section{Author details}

${ }^{1}$ Department of Pharmacy, Jashore University of Science and Technology, Jashore-7408, Jashore, Bangladesh. ²Department of Pharmacy, Stamford University Bangladesh, 51, Siddeswari Road, Dhaka -1217, Bangladesh. ${ }^{3}$ School of Biomedical Sciences, Charles Sturt University, Wagga Wagga, Australia. ${ }^{4}$ Department of Pharmacy, Jahangirnagar University, Savar, Dhaka -1342, Bangladesh.

Received: 31 May 2019 Accepted: 6 November 2019

Published online: 19 November 2019

\section{References}

1. Craig CR, Stitzel RE. Modern Pharmacology with Clinical Applications. 5th ed. Philadelphia: Lippincott Williams \& Wilkins; 2003. p. 832.

2. Boursinos LA, Karachalios T, Poultisides L, Malizos M. Do steroids, conventional non-steroidal anti-inflammatory drugs and selective Cox-2 inhibitors adversely affect fracture healing. J Mus Neuro Inter. 2009;9:44-52.

3. Sparkes A, Heiene R, Lascelles BD, Malik R, Sampietro LR, et al. NSAIDs and cats- it's been a long journey. J Fel Med Sur. 2010;12:519-38.

4. Koech SC, Ouko RO, Michael NM, Ireri MM, Ngugi MP, Njagi NM. Analgesic activity of Dichloromethanolic root extract of Clutia abyssinica in Swiss albino mice. Nat Prod Chem Res. 2017;5:255. https://doi.org/10.4172/23296836.1000255

5. Yasmen N, Aziz MA, Tajmim A, Hazra AK, Akter MI, Rahman SMM. Analgesic and Anti-Inflammatory Activities of Diethyl Ether and n-Hexane Extract of Polyalthia suberosa Leaves. Evid Based Complement Alternat Med. 2018; 2018:5617234

6. Wallace JL. Pathogenesis of NSAID induced gastro duodenal mucosal injury. B Prac Res: Clin Gastro. 2001;15:691-703.

7. Shih SC and C.-W. Chang CW. Nonsteroidal anti-inflammatory drug-related gastrointestinal bleeding in the elderly. Int J Gero. 2007; 1: 40-45.

8. Joshua. "Difference between NSAIDs and Steroids," DifferenceBetween. net,"2017, http://www.differencebetween.net/science/health/drugs-health/ difference-between nsaids-and-steroids/.

9. Brennan M. Adverse effects of NSAIDs on renal function. Can Med Asso J. 1984;131(9):1012-3.

10. Guedes IA, Magalhães CS, Dardenne LE. Receptor-ligand molecular docking Biophyl rev. 2014;6(1):75-87.

11. Paul A. Anticancer potential of isolated phytochemicals from Ocimum sanctum against breast cancer: In silico Molecular docking approach. National Conference on "Biochemistry and Molecular Biology for Life Sciences" At: University of Dhaka. 2016. https://doi.org/10.13140/RG.2.2. 20939.18725.

12. Nain P, Kumar S, Nain J, Kumar S. Evaluation and comparison of anxiolytic effect of flax seed oil and perilla oil in rats. Inter Res J Pharm. 2011;2:161-4.

13. Di Pietro C, Seamans JK. Dopamine and serotonin interactions in the prefrontal cortex: insights on antipsychotic drugs and their mechanism of action. Pharmacopsych. 2007;40:S27-33.

14. https://en.wikipedia.org/wiki/Lippia alba. Accessed 12 July 2018.

15. Duke JA. Duke's Handbook of Medicinal Plants of Latin America. CRC Press. 2008:412-4

16. La Pitiona. http://www.pitiona.com/english/the-restaurant/la-pitiona/. Accessed 12 Apr 2019.

17. L. alba: Prontoalivio, Erva cidreira, juanilama, Melissa. United Nations Conference on Trade and Development. 2005. https://docplayer.net/56151 078-Lippia-alba-prontoalivio-erva-cidreira-juanilama-melissa.html.

18. Haldar S, Kar B, Dolai N, Kumar RBS, Behera B, Haldar PK. In vivo antinociceptive and anti-inflammatory activities of $L$. alba. Asian Pac. J Trop Dis. 2012:2:S667-70. 
19. Tomazoni EZ, Pansera MR, Pauletti GF, Moura S, Ribeiro RTS, Schwambach J. In vitro antifungal activity of four chemotypes of L. alba (Verbenaceae) essential oils against Alternaria solani (Pleosporeaceae) isolates. Ann Braz Acad Sci. 2016;88(2):999-1010.

20. Mamun-Or-Rashid ANM, Sen MK, Jamal MAHM, Nasrin SA. Comprehensive ethno-pharmacological review on L. alba M. Int J Biomed Mater Res. 2013; 1(1):14-20.

21. Pascual ME, Slowing K, Carretero ME, Villar A. Antiulcerogenic activity of L. alba (mill.) N. E. Brown (Verbenaceae). II Farmaco. 2001;56:501-4.

22. Glamoclija J, Sokovic M, Tesevic $V$, et al. Chemical characterization of $L$. alba essential oil: an alternative to control green molds. Bra J Micro. 2011;42:1537-42.

23. Timotio P, Karioti A, Leitao SG, et al. HPLC/DAD/ESI-MS analysis of nonvolatile constituents of three Brazilian Chemotypes of L. alba (mill.) N. E. Brown. Nat Pro Cyom. 2008;3(12):2017-20.

24. Walum E. Acute oral toxicity. Environ Health Perspect. 1998;106:497-503.

25. Koster R, Anderson M, De-Beer EJ. Acetic acid analgesic screening. Fed Proc. 1959;18:412-7.

26. Toma W, Graciosa JS, Hiruma-Lima CA, Andrade FDP, Vilegas W, Souza Brita ARM. Evaluation of analgesic and antiedematogenic activities of Quassia Amara bark extract. J Ethnopharmacol. 2003;85:19-23.

27. Kurumbail RG, Stevens AM, Gierse JK, et al. Structural basis for selective inhibition of cyclooxygenase-2 by anti-inflammatory agents. Nature. 1996;384:644-8.

28. Hasanat A, Chowdhury TA, Kabir MSH, Chowdhury MS, Chy MNU, Barua J, Chakrabarty N, Paul A. Antinociceptive Activity of Macaranga denticulata Muell. Arg. (Family: Euphorbiaceae): In Vivo and In Silico Studies. Medicines. 2017:4(4):88

29. Paul A, Adnan M, Majumder M, et al. Anthelmintic activity of Piper sylvaticum Roxb. (family: Piperaceae): In vitro and in silico studies. Cli Phy. 2018;4:17.

30. Friesner RA, Banks JL, Murphy RB, Halgren TA, Klicic JJ, Mainz DT, et al. Glide: a new approach for rapid, accurate docking and scoring. 1. Method and assessment of docking accuracy. J Med Chem ACS Publications. 2004;47: 1739-49.

31. Halgren TA, Murphy RB, Friesner RA, Beard HS, Frye LL, Pollard WT, et al. Glide: a new approach for rapid, accurate docking and scoring. 2. Enrichment factors in database screening. J med Chem. ACS Publications. 2004;47:1750-9.

32. https://en.wikipedia.org/wiki/Lipinski\%27s_rule_of_five. Accessed 12 July 2018.

33. Alabri THA, Musalami AHSA, Hossain MA, Al-Riyami AMWQ. Comparative study of phytochemical screening, antioxidant and antimicrobial capacities of fresh and dry leaves crude plant extracts of Datura metel L. J King Saud Univ Sci. 2014;26:237-43.

34. Kashani HH, Hoseini ES, Nikzad H, Aarabi MH. Pharmacological properties of medicinal herbs by focus on secondary metabolites. Life Sci J. 2012;9(1):509-20.

35. Nakka S, Devendra BN. A rapid in vitro propagation and estimation of secondary metabolites for in vivo and in vitro propagated Crotalaria species, a Fabaceae member. J Microbiol Biotechnol Food Sci. 2012;2(3):897-916.

36. Jaman MU, Sultana F, Chowdhury MAR, Hossain MT, Haque MIU. In vivo assay of analgesic activity of methanolic and petroleum ether extracts of Manilkara zapota leaves. Br J Pharm Res. 2014;4(2):186-91.

37. Ronaldo AR, Mariana LV, Sara MT, Adriana BPP, Steve P. Involvement of resident macrophages and mast cells in the writhing nociceptive response induced by zymosan and acetic acid in mice. Eur J Pharmacol. 2000;387:111-8.

38. Voilley N. Acid-sensing ion chanels (ASICS): new targets for the analgesic effects of non-steroidal anti-inflammatory drugs (NSAIDs). Curr Drug Targets Inflamm Allergy. 2004;3:71-9.

39. Hossain MM, Ali MS, Saha A. Antinociceptive activity of whole plant extracts of Paederia foetida. Dhaka Univ J Pharm Sci. 2006;5:67-9.

40. Muzammil AS, Farhana T, Salman A. Analgesic activity of leaves extracts of Samanea saman Merr. And Prosopis cineraria Druce. Int Res J Pharm. 2013; 4(1):93-5.

41. Oluwatoyin AE, Adewale AA, Isaac AT. Anti-nociceptive and antiinflammatory effects of a nigerian polyherbal tonic tea (pht) extract in rodents. Afr J Tradit Complement Altern Med. 2008;5(3):257-62.
42. Lee $Y$, Rodriguez C, Dionne RA. The role of COX-2 in acute pain and the use of selective COX-2 inhibitors for acute pain relief. Curr Pharm Des. 2005; 11(14):1737-55.

43. Mattia C, Coluzzi F. COX-2 inhibitors: pharmacological data and adverse effects. Minerva Anestesiol. 2005;71(7-8):461-70.

\section{Publisher's Note}

Springer Nature remains neutral with regard to jurisdictional claims in published maps and institutional affiliations.

\section{Submit your manuscript to a SpringerOpen ${ }^{\circ}$ journal and benefit from:}

- Convenient online submission

- Rigorous peer review

- Open access: articles freely available online

- High visibility within the field

- Retaining the copyright to your article

Submit your next manuscript at $\boldsymbol{\nabla}$ springeropen.com 